\title{
Effect of experimental zinc deficiency and repletion on some immunological variables in guinea-pigs
}

\author{
By P. C. VERMA, R. P. GUPTA, J. R. SADANA AND R. K. PAUL GUPTA \\ Department of Veterinary Pathology, College of Veterinary Sciences, Haryana \\ Agricultural University, Hisar-125 004, India
}

(Received 5 June 1987 - Accepted 16 September 1987)

\begin{abstract}
1. Cellular and humoral immune responses were studied in guinea-pigs fed on zinc-deficient ( $\mathrm{ZnD}), \mathrm{Zn}$ adequate (control) and $\mathrm{Zn}$-replete diets containing $1 \cdot 25,50$ and $100 \mathrm{mg} \mathrm{Zn} / \mathrm{kg}$ diet respectively.

2. It was found that the $\mathrm{ZnD}$ guinea-pigs had significantly decreased ability to elicit delayed-type hypersensitivity (DTH) response against sheep erythrocytes as compared with controls on the 9 th day of immunization. This was further substantiated by histological examination of DTH-positive skin sections.

3. A significant reduction in direct splenic plaque-forming-cell response and haemagglutinating-antibody titre was also observed in $\mathrm{ZnD}$ guinea-pigs.

4. Serum electrophoretic studies revealed a highly disordered protein profile with a significantly depressed value for $\gamma$-globulin.

5. $\mathrm{Zn}$ repletion of the previously $\mathrm{ZnD}$ group resulted in marked, though incomplete, restoration of immunological responses.
\end{abstract}

Zinc plays an indispensable role in the development and maintenance of immunocompetence and a number of other body-functions. Natural cases of its deficiency in man and domestic animals have been reported throughout the world. Human patients with low levels of serum $\mathrm{Zn}$, and cattle having heritable disorders of $\mathrm{Zn}$ metabolism (Gershwin et al. 1985), had increased susceptibility to a variety of infectious disorders and defective cellmediated immunity. There is little published work on immunological studies of experimental $\mathrm{Zn}$ deficiency in laboratory animals, particularly in guinea-pigs in which cellmediated allergic reactions are readily induced and evaluated (Parker \& Turk, 1974). The only report (Carlomagno et al. 1985) traced in the literature on immunological observations in experimental $\mathrm{Zn}$-deficient $(\mathrm{ZnD})$ guinea-pigs revealed that $\mathrm{Zn}$ deficiency suppressed the delayed-type hypersensitivity (DTH) response. The present work was undertaken, therefore, to study the effect of experimental $\mathrm{Zn}$ deficiency and repletion on certain cellular and humoral immune responses in guinea-pigs.

\section{MATERIALS AND METHODS}

\section{Animals and diets}

Recently weaned albino guinea-pigs (21-d-old) of an inbred colony of the English breed, weighing about 200-250 g, were obtained from the Disease-Free Small Animal House, Haryana Agricultural University, Hisar. These were fed ad lib. on a purified diet, the details of which have already been described (Gupta et al. 1985). All animals were kept individually in plastic cages and provided with double-distilled water ad lib. To avoid coprophagy, perforated acrylic sheets were fixed at the bottom of the cages.

\section{Experimental design}

The guinea-pigs were randomly divided into two groups containing twelve and six animals respectively. Animals of the first group were fed on a $\mathrm{ZnD}$ diet containing 1.25 (SE 0.12) $\mathrm{mg} \mathrm{Zn} / \mathrm{kg}$ for $45 \mathrm{~d}$, and then divided into two subgroups of six animals each. The animals 
of subgroup 1 continued to receive the $\mathrm{ZnD}$ diet while animals of subgroup 2 were given a $\mathrm{Zn}$-replete $(\mathrm{ZnR})$ diet $(100 \mathrm{mg} \mathrm{Zn} / \mathrm{kg}$ diet $)$. All animals of the second main group were fed on a control $\mathrm{Zn}$-adequate diet $(50 \mathrm{mg} \mathrm{Zn} / \mathrm{kg}$ diet) throughout the experiment.

All guinea-pigs were closely observed daily for clinical signs.

\section{Serum $\mathrm{Zn}$ analysis}

Blood was collected from the heart at the start of the experiment and then at days 45 and 60 of the experiment in sterilized tubes for serum separation. Serum $\mathrm{Zn}$ concentration was estimated using atomic absorption spectrophotometry (Horwitz, 1965).

\section{Antigen}

Sheep erythrocytes (SRBC) were used as the antigen in these studies. Fresh blood from a healthy sheep was collected in Alsever's solution. Before use, this was washed three times in 0.01 M-sodium-phosphate-buffered saline (9 $\mathrm{g}$ sodium chloride/l: $\mathrm{PBS}), \mathrm{pH} 7 \cdot 2$.

\section{Immunization}

All guinea-pigs of different experimental groups were inoculated subcutaneously with $2 \times 10^{8} \mathrm{SRBC}$ (suspended in PBS) in the hind-foot pad on day 60 of the experiment.

\section{DTH response}

SRBC-specific DTH reaction was elicited in guinea-pigs by injecting $25 \mu$ l SRBC $\left(5 \times 10^{7}\right)$ in PBS $(100 \mathrm{ml} / 1)$ into the dorsal side of the right ear of each animal on the 8 th day of immunization. An equal amount ( $25 \mu \mathrm{l})$ of PBS was injected into the dorsal side of the left ear, which served as control. DTH reaction was determined by measuring the specific increase in ear thickness $24 \mathrm{~h}$ after injection of the eliciting antigen as described by Tamura et al. (1973). For histological studies of DTH reaction, a piece of skin from the right and left ears was collected into buffered formal-saline solution $(100 \mathrm{ml} / \mathrm{l})$. Paraffin sections, 4-5 $\mu \mathrm{m}$ thick, were cut and stained with haemotoxylin and eosin.

\section{Direct splenic plaque-forming cell (PFC) count}

Guinea-pigs of different groups were killed on the 69th day of the experiment and their spleens were removed aseptically, The total number of direct-PFC per million spleen cells was determined by the Jerne Plaque assay (Jerne, 1974).

\section{Haemagglutinating-antibody $(H A)$ titre}

HA titres were determined by the microtitre method (Tamura et al. 1973) in the sera of all guinea-pigs immediately after measuring DTH reaction.

\section{Serum proteins}

Total serum protein concentration was determined by the Biuret method (Wootton, 1974) and its fractions by paper electrophoresis (Huisman, 1963) on the day of immunization and thereafter on the 9 th day of immunization.

\section{Statistical analysis}

The statistical significance was assessed by Student's ' $t$ ' test.

$\mathrm{Zn}$ deficiency was successfully produced experimentally within $45 \mathrm{~d}$ in the guinea-pigs given the $\mathrm{ZnD}$ diet as evidenced by clinical signs and a reduction in serum $\mathrm{Zn}$ level. Food intake 
among different experimental groups of guinea-pigs was almost identical throughout the experiment.

\section{DTH response}

The average increase in skin thickness and degree of cellular reactions in different experimental groups are given in Table 1. It was observed that the mean increase in skin thickness due to SRBC-specific DTH was significantly $(P<0.01)$ lower in the $\mathrm{ZnD}$ group as compared with the control. Although an increased skin thickness in the ZnR group was also noticed, the difference from the control value was not significant.

A swelling in the form of induration and nodulation appeared at the site of injection in the right ear but no such swelling was perceptible in the left ear (control). Histological examination of the indurated area of skin from guinea-pigs given a control $\mathrm{Zn}$-adequate diet revealed oedema and intense infiltration of lymphocytes, macrophages and neutrophils in the dermis (Plate $1(a)$ ). The cellular infiltration was mainly around the blood vessels. In the $\mathrm{ZnD}$ group, the oedema and cellular infiltration was of a very-mild degree (Plate $1(b)$ ) while in the ZnR group it was almost of the same intensity as that of the control group. No oedema or cellular infiltration was noticed in sections from the left (control) ear.

\section{PFC and haemagglutination assay}

The mean direct-PFC per million spleen cells and HA titres for each experimental group are given in Table 2. It is apparent that the mean PFC per million spleen cells and HA titres were significantly $(P<0.01)$ lower in the $\mathrm{ZnD}$ group compared with the control group. The $\mathrm{ZnR}$ group also showed lower values, in comparison with those of the controls, but the differences were not significant.

\section{Serum proteins}

Mean values for total serum protein and the different serum protein fractions for each experimental group are shown in Table 3 . Total serum protein concentration in the $\mathrm{ZnD}$ group was significantly $(P<0.05)$ lower than that in the control group on the 60th day of the experiment, at which time the guinea-pigs were immunized to SRBC antigen. Electrophoretic evaluation of serum from the $\mathrm{ZnD}$ group also revealed a highly disordered distribution of the protein profile with significantly $(P<0.01)$ decreased levels of $\gamma$ globulin and albumin as compared with the controls. The value for $\gamma$-globulin in the $\mathrm{ZnD}$ group $9 \mathrm{~d}$ post-immunization was almost the same as that on the day of immunization, but in the control group there was a considerable increase in the $\gamma$-globulin level. In the ZnR group, the $\gamma$-globulin level was slightly increased but the difference when compared with the control group was not significant.

\section{DISCUSSION}

Anorexia is generally accepted as inevitable during $\mathrm{Zn}$ deficiency and pair-feeding with a $\mathrm{Zn}$-adequate control diet is considered to be necessary. However, in the present study food intake by the animals in different groups was almost identical. McBean et al. (1972) and Gupta et al. (1985) also did not notice any effect of $\mathrm{Zn}$ deficiency on food intake in guineapigs. Thus the results reported in the present study are of pure $\mathrm{Zn}$ deficiency unaccompanied by reduced food intake.

The results of the cell-mediated immune (CMI) response to SRBC in the present study are in accordance with the findings of Fraker et al. (1982) in mice and Carlomagno et al. (1985) in guinea-pigs. They reported impairment of DTH responses to dinitrofluorobenzene and tuberculin respectively in $\mathrm{ZnD}$ animals. Cellular reactions of DTH observed in the present study are almost similar to that reported by Mitsuoka et al. (1978) in SRBC-immunized mice. The DTH responses are complex and involve interplay between 
Table 1. Delayed-type hypersensitivity response in zinc-deficient, Zn-repleted and control guinea-pigs immunized with sheep erythrocytes $\dagger$

(Mean values with their standard errors for six animals/group)

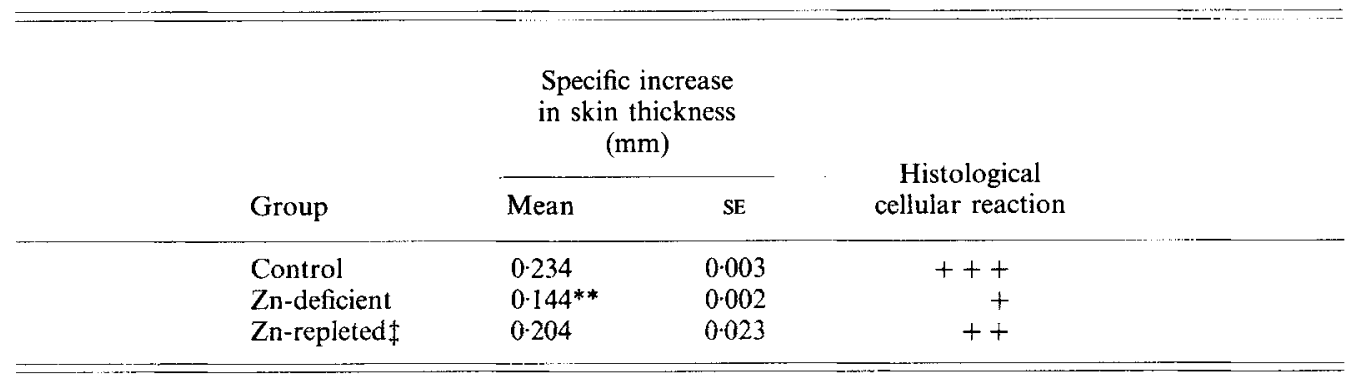

+++ , Intense; ++ , moderate; + , mild.

Mean values were significantly different from those of the control group: ${ }^{* *} P<0 \cdot 01$.

+ For details of diets and immunization procedures, see pp. 149-150.

+ Repleted on 45th day of depletion.

Table 2. Antibody-mediated immune responses in zinc-deficient, Zn-repleted and control guinea-pigs immunized with sheep erythrocytes $\dagger$

(Mean values with their standard errors for six animals/group)

\begin{tabular}{|c|c|c|c|c|}
\hline \multirow[b]{2}{*}{ Group } & \multicolumn{2}{|c|}{$\begin{array}{c}\text { Direct } \mathrm{PFC} / 10^{6} \\
\text { spleen cells }\end{array}$} & \multicolumn{2}{|c|}{ HA titre } \\
\hline & Mean & $\mathrm{SE}$ & Mean & $\mathrm{SE}$ \\
\hline Control & $540 \cdot 00$ & 67.08 & 6.40 & $0 \cdot 88$ \\
\hline Zn-deficient & $140 \cdot 00^{* *}$ & $27 \cdot 38$ & $2 \cdot 00^{* *}$ & 0.57 \\
\hline Zn-repleted + & $460 \cdot 00$ & $120 \cdot 41$ & $5 \cdot 60$ & 0.88 \\
\hline
\end{tabular}

PFC, plaque-forming cells; HA, haemagglutinating antibody.

Mean values were significantly different from those for the control group: ${ }^{* *} P<0.01$.

$\dagger$ For details of diets and immunization procedures, see pp. 149-150.

$\$$ Repleted on 45th day of depletion.

the $T_{D}$ sub-population of T-lymphocytes (T-cells) and secreted mediators as well as macrophages, the detailed mechanism of which is not yet completely understood. Lyt-1 T helper cells, which are closely related to $T_{D}$ lymphocytes (Askenase, 1980), have shown altered functionality both in vivo against antigen and in vitro against conconavalin $\mathrm{A}$ (DePasquale-Jardieu \& Fraker, 1981) during $\mathrm{Zn}$ deficiency in mice. Since a reduction in in vivo performance of T-cells involved in CMI response has been reported in $\mathrm{ZnD}$ animals (Fernandes et al. 1979; Chandra \& Au, 1980), it may be inferred that at least part of the reduction in DTH in $\mathrm{Zn}$ deficiency is due to a reduction in $T_{D}$ effector functions.

Splenic PFC counts have been reported only as an index of humoral immune stimulation against SRBC in Zn-deficient animals (Fernandes et al. 1979; Beach et al. 1980) without concomitant measurement of antibody titre response which is one of the valid functional indices of humoral immunity. In the present study, however, a significant reduction in HA titre was observed in $\mathrm{ZnD}$ guinea-pigs together with a marked reduction in direct $\mathrm{PFC}$ response to $\mathrm{SRBC}$ compared with the controls. These results indicate that $\mathrm{Zn}$ deficiency per se causes extensive impairment of $\mathrm{T}$-helper cell functions that are required for optimal 
Table 3. Total serum protein and serum protein fractions $(\mathrm{g} / \mathrm{l})$ in zinc-deficient, $\mathrm{Zn \text {-repleted }}$ and control guinea-pigs at 0 and 9 th days of immunization with sheep erythrocytes $\dagger$

(Mean values with their standard errors for six animals/group)

\begin{tabular}{|c|c|c|c|c|}
\hline \multirow[t]{2}{*}{ Day of immunization $\cdots$} & \multicolumn{2}{|c|}{0} & \multicolumn{2}{|c|}{9} \\
\hline & Mean & $\mathrm{SE}$ & Mean & $\mathrm{SE}$ \\
\hline \multicolumn{5}{|l|}{ Zn-deficient } \\
\hline Total protein & $54^{*}$ & $3 \cdot 1$ & $56^{*}$ & $0 \cdot 2$ \\
\hline Albumin & $32 * *$ & $0 \cdot 3$ & $33^{* *}$ & 0.7 \\
\hline$\alpha$-Globulin & 12 & 0.4 & 13 & $0 \cdot 3$ \\
\hline$\beta$-Globulin & 7 & $0 \cdot 3$ & 7 & $0 \cdot 2$ \\
\hline$\gamma$-Globulin & $1 \cdot 5^{* *}$ & $0 \cdot 3$ & $2 * *$ & 0.1 \\
\hline \multicolumn{5}{|l|}{ Zn-repleted $\ddagger$} \\
\hline Total protein & 77 & $5 \cdot 2$ & 78 & $2 \cdot 8$ \\
\hline Albumin & 50 & $1 \cdot 5$ & 50 & 0.6 \\
\hline$\alpha$-Globulin & 16 & $0 \cdot 9$ & 17 & 0.6 \\
\hline$\beta$-Globulin & 8 & 10 & 7 & 0.5 \\
\hline$\gamma$-Globulin & 4 & $1 \cdot 2$ & 5 & 0.5 \\
\hline \multicolumn{5}{|l|}{ Control } \\
\hline Total protein & 75 & $7 \cdot 3$ & 80 & $2 \cdot 9$ \\
\hline Albumin & 48 & 0.8 & 49 & 0.3 \\
\hline$\alpha$-Globulin & 14 & $1 \cdot 0$ & 16 & 0.5 \\
\hline$\beta$-Globulin & 6 & $0 \cdot 6$ & 7 & 0.1 \\
\hline$\gamma$-Globulin & 6 & 0.5 & 10 & $2 \cdot 3$ \\
\hline
\end{tabular}

Mean values were significantly different from those of the control group: ${ }^{*} P<0.05, * * P<0.01$.

$\dagger$ For details of diets and immunization procedures, see pp. 149-150.

$\$$ Repleted on 45th day of depletion.

antibody-mediated response (Borum, 1972) against thymus-dependent antigen (SRBC). The studies of Fraker et al. (1977) have clearly demonstrated that the impairment is primarily attributable to T-helper cells and may have little effect on B lymphocytes.

Limited information appears to be available in the literature regarding the serum protein profile of immunized $\mathrm{ZnD}$ animals. Beach et al. (1980) observed a high variation in the serum immunoglobulin profile without any significant change in the total $\gamma$-globulin level on the 4th day of immunization to SRBC in ZnD mice. In the present study, however, the $\gamma$-globulin concentration in the $\mathrm{ZnD}$ group was significantly $(P<0.01)$ lower than that of the controls on the 9 th day of immunization. These results also suggest that $\mathrm{Zn}$ deficiency does have an adverse effect on antibody-mediated immune response. Impairment of cellular and humoral immune responses due to $\mathrm{Zn}$ deficiency may be due partly to decreased activity of DNA polymerase, RNA polymerase and thymidin kinase (Kirchgessner et al. 1976) which are required for rapid proliferation of immunocytes and protein synthesis.

The findings for the $\mathrm{ZnR}$ group showed that there was marked, though incomplete, restoration of immunological response. Very similar observations for $\mathrm{Zn}$ repletion have been made in mice (Fraker et al. 1978, 1982). However, it may be necessary to examine whether the impairment of immunological functions observed as a result of dietary $\mathrm{Zn}$ deficiency is completely reversible following repletion or whether there remain certain irreversible features of this condition, since repletion studies were carried out for $15 \mathrm{~d}$ only. 


\section{REFERENCES}

Askenase, P. (1980). In In Academic Press.

Beach, R. S., Gershwin, M. E., Makishima, R. K. \& Hurley, L. S. (1980). Journal of Nutrition 110, 805-815.

Borum, K. (1972). Acta Pathologica et Microbiologica Scandinavica 80, 287-288.

Carlomagno, M. A., Mintzer, C. L., Tetzlaff, C. L. \& Mchurray, D. N. (1985). Nutrition Research 5, $959-968$.

Chandra, R. K. \& Au, B. (1980). American Journal of Clinical Nutrition 33, 736-738.

DePasquale-Jardieu, P. \& Fraker, P. J. (1981). Federation Proceedings 40, 1130.

Fernandes, H., Nair, M., Onoe, K., Tanaka, T., Floyd R. \& Good, R. (1979). Proceedings of the National Academy of Sciences, USA 76, 457-461.

Fraker, P. J., Haus, S. \& Luecke, R. W. (1977). Journal of Nutrition 107, 1889-1895.

Fraker, P. J., Jardieu, P. M., Zwickl, C. M. \& Luecke, R. W. (1978). Proceedings of the National Academy of Sciences, USA 75, 5660-5664.

Fraker, P. J., Zwickl, C. M. \& Luecke, R. W. (1982). Journal of Nutrition 112, 309-313

Gershwin, M. E., Beach, R. S. \& Hurley, L. S. (1985). Nutrition and Immunity. New York: Academic Press.

Gupta, R. P., Verma, P. C. \& Gupta, R. K. P. (1985). British Journal of Nutrition 54, 421-428.

Horwitz, W. (1965). Official Methods of Analysis of the Association of Official Analytical Chemists, p. 193.

Washington, DC: Ben Franklin Press.

Huisman, T. H. I. (1963). Advances in Clinical Chemistry 6, 246-249.

Jerne, N. K. (1974). Transplant Reviews 18, 130-191.

Kirchgessner, M., Roth, H. P. \& Weigand, E. (1976). In Trace Elements in Human Health and Disease, vol. 1 Zinc and Copper, p. 189 [A. Prasad, editor]. New York: Academic Press.

McBean, L. D., Smith, J. C. Jr \& Halsted, J. A. (1972). Proceedings of the Society for Experimental Biology and Medicine 140, 1207-1209.

Mitsuoka, T., Teramatsu, M., Baba, S. M. \& Yaswhira, K. (1978). Immunology 34, 363-370.

Parker, D. \& Turk, J. L. (1974). Contact Hypersensitivity in Experimental Animals, Monograph on Allergy, vol 8. Basel: Karger.

Tamura, S., Kurata, T., Sugimoto, M. \& Egashira, Y. (1973). Japanese Journal of Medical Science and Biology 26, 161-166.

Wootton, I. D. P. (1974). Microanalysis in Medical Biochemistry, pp. 156-158. London: J. A. Churchill Livingstone.

\section{EXPLANATION OF PLATE}

Plate 1. Oedema and intense mononuclear infiltration in delayed-type hypersensitivity positive skin section (ear) of a guinea-pig given (a) a control, zinc-adequate diet and $(b)$ a $\mathrm{Zn}$-deficient diet (for details see pp. 149-150). Haematoxylin and eosin stain; magnification $\times 100$. 
British Journal of Nutrition, Vol. 59, No. 1
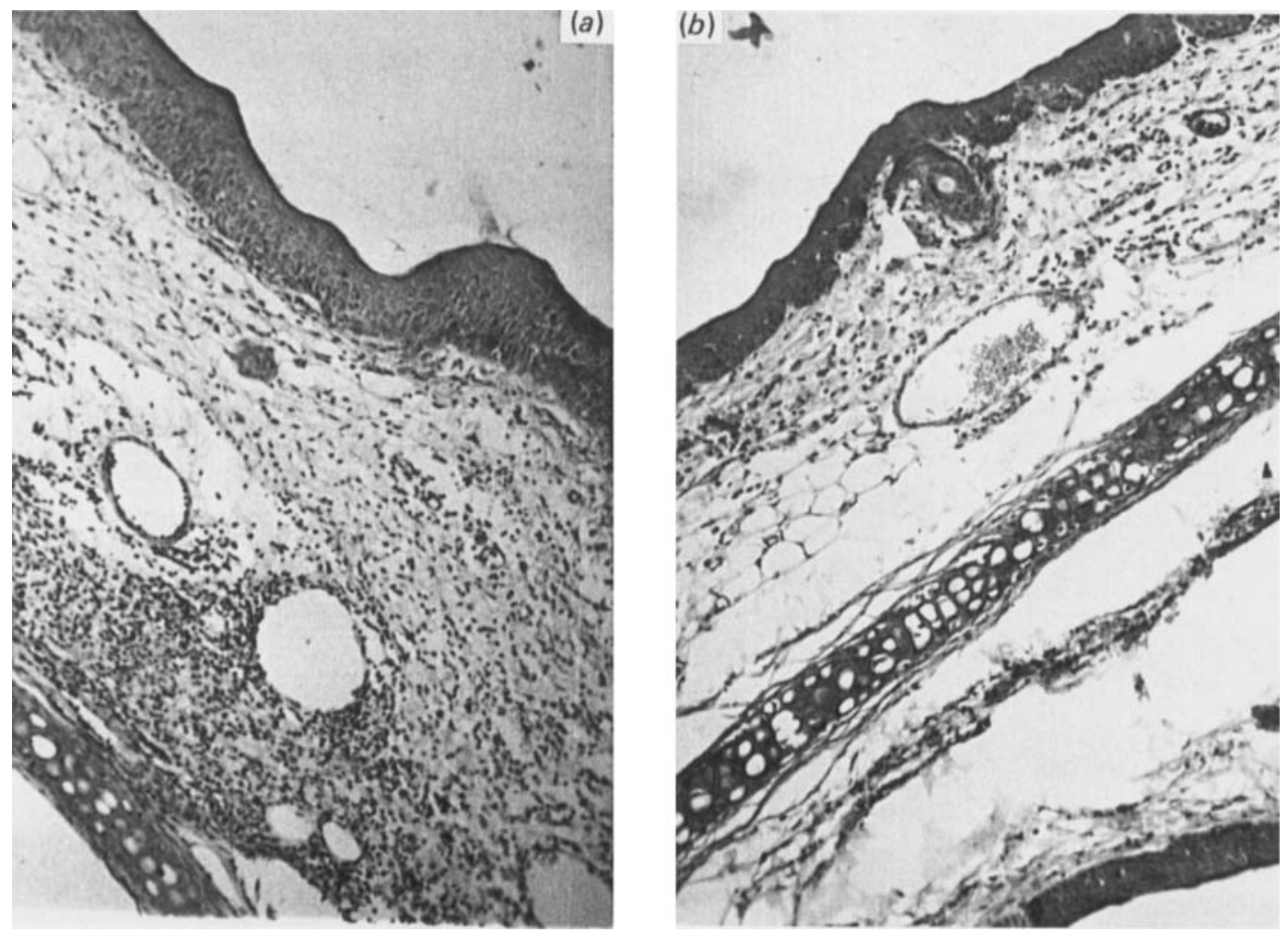